\title{
ASSOCIATION BETWEEN VITAMIN D LEVELS AND ACTIVITY OF SYSTEMIC ERITEMATOSUS LUPUS: A RETROSPECTIVE STUDY OF AN OUTPATIENT CLINIC
}

\author{
PATRICK FONTES RODRIGUES (UNIVERSIDADE ESTADUAL DO OESTE DO PARANÁ, CASCAVEL, PR, Brasil), \\ LUIZ PIERRE HUNING (UNIVERSIDADE ESTADUAL DO OESTE DO PARANÁ, CASCAVEL, PR, Brasil), ANA \\ PAULA ADAME (UNIVERSIDADE ESTADUAL DO OESTE DO PARANÁ, CASCAVEL, PR, Brasil), MARCIO \\ AUGUSTO NOGUEIRA (UNIVERSIDADE ESTADUAL DO OESTE DO PARANÁ, CASCAVEL, PR, Brasil)
}

\section{BACKGROUND}

Systemic lupus erythematosus (SLE) is a chronic, incurable, rare and complex disease; and its global burden remains undervalued and poorly understood. Vitamin D (VD), considered a prehormone, is much discussed at present, mainly due to its extraskeletal effects. It is considered one of the major environmental contributors to the development of autoimmune diseases. Thus, several recent studies have emerged with the objective of identifying a possible association of hypovitaminosis $D$ and disease activity in SLE.

\section{MATERIALS AND METHODS}

This quantitative, retrospective, documentary, longitudinal and correlational study questions the effects of serum levels of VD in patients with SLE, in order to defend the hypothesis that higher vitamin levels are associated with less activity of the disease. Thus, 59 patients with 239 VD dosages were selected from 2010 to 2018 in Rheumatology outpatient clinic of a tertiary hospital in the region studied. These dosages were correlated with several laboratory tests in search of association with disease activity. For this, two groups were defined in relation to VD levels, insufficient (VD $<30 \mathrm{ng} / \mathrm{mL}$ ) and sufficient (VD $\geq 30$ $60 \mathrm{ng} / \mathrm{mL}$ ), and compared information among them.

\section{RESULTS}

Approximately $49.60 \%$ of the dosages were insufficient for the VD levels in SLE. Levels lower of VD were associated with some laboratory abnormalities and increased disease activity, which is consistent with previous studies. There was a statistically significant difference in the values of hemoglobin, urea, creatinine and LDL levels between the groups with a sufficient VD level ( ${ }^{1} p=0.01, p=0.02, p<0.01$ and $p$ $=0.02$, respectively, according Mann-Whitney test). When analyzing levels of VD, with disease activity, relevant values were observed when 24-hour proteinuria and erythrocyte sedimentation rate were assessed $\left({ }^{2} p=0.03\right.$ and $p=0.04$, according $X^{2}$ test).

\section{CONCLUSION}

The present study advocate that vitamin D deficiency in individuals with SLE are associated with disease activity (including renal disease) and cardiovascular risk. Therefore, this work reiterates that it is necessary to conduct larger samples and controlled clinical trials in an attempt to define better management and goals of vitamin D, with a focus on disease control, to improve the quality of life of these patients. 